\title{
Dry matter accumulation and remobilization of durum wheat as affected by soil gravel content
}

\author{
Laura Ercoli ${ }^{1 *}$, Alessandro Masoni ${ }^{2}$, Marco Mariotti', Iduna Arduini' \\ 'Scuola Superiore Sant'Anna di Studi Universitari e di Perfezionamento, Piazza Martiri della \\ Libertà 33, 56127, Pisa, Italy \\ ${ }^{2}$ Dipartimento di Agronomia e Gestione dell'Agroecosistema, via S. Michele degli Scalzi 2, \\ 56124, Pisa, Italy \\ *Corresponding author: ercoli@sssup.it
}

\begin{abstract}
Summary
Soil gravel content affects many soil physical properties, i.e. bulk density, porosity, water infiltration and storage, as well as crop yield. Little is known regarding the influence of soil gravel content on grain yield of durum wheat (Triticum durum Desf.). In this paper the accumulation of dry matter during the vegetative and reproductive periods and the contribution of pre-anthesis assimilates to grain yield have been evaluated in two durum wheat varieties grown on soils with $0,10,20$, and $30 \%$ gravel content. The two varieties showed similar behaviour and more soil gravel decreased plant biomass both at anthesis and at maturity. Soil gravel content greatly reduced grain yield and dry weight of all plant parts both at anthesis and maturity. Post-anthesis dry matter accumulation was $16 \%$ lower in plants grown on $30 \%$ gravel soil and dry matter remobilization was 53\% lower, compared to plants grown in gravel-free soil. The differences in growth rate were attributed to the restriction of the volume of soil available for root growth.
\end{abstract}

Keywords: accumulation, dry matter, durum wheat, grain filling, gravel content, remobilization

\section{INTRODUCTION}

Soils containing rock fragments are widespread, particularly in the Mediterranean area where they often occupy more than $60 \%$ of the land surface (Poesen, 1990). Soils rich in rock fragments are found on erosional as well as on depositional landforms, but high rock fragment contents in top soils can also be attributed to intensive cultivation, owing to tillage erosion and water erosion (Poesen and Lavee, 1994).

Plough layers containing rock fragments have a higher macro-porosity, saturated hydraulic conductivity and daily maximum temperature than stone-free soils (Ravina and Magier, 1984; Poesen and Ingelmo-Sanchez, 1992; Danalatos et al., 1995). Stony soils have also a lower fine earth bulk density compared to stone-free soils, which can lead to deeper penetration of rain (Ravina and Magier, 1984; van Wesemael et al., 1996).

Little research has addressed the effects of rock fragment content of soil on plant growth and crop productivity. In the semiarid climatic zone, where water availability is the dominant factor affecting biomass production of wheat, rock fragments exert a negative effect on wheat productivity in normal or wet years, but in dry years they promote deep percolation of water in soil and save appreciable amounts of water from evaporation by surface mulching, thereby increasing crop yields (Kosmas et al., 1993 and 1994). Experiments with deep lysimeters in the Western Desert (USA) showed that recharge of groundwater was more pronounced in soils containing a higher content of rock fragments (Gee et al., 1994). 
In winter cereals, the supply of assimilate to grain originates from current assimilation transferred directly to kernels and from the remobilization of assimilates stored temporarily in vegetative plant parts before anthesis (Gebbing et al., 1999). After anthesis, plants continue growth, and significant quantities of biomass can be produced during grain filling (Austin et al., 1977; Cox et al., 1985). Reserves deposited in vegetative plant parts before anthesis may buffer grain yield against conditions adverse to crop growth during the grain filling period. Van Herwaarden et al. (1998) showed that under dry field conditions, the apparent contribution of stored assimilates could be $75-100 \%$ of grain yield, as compared with $37-39 \%$ under high rainfall conditions. Austin et al. (1977) and Bidinger et al. (1977) estimated that stem carbohydrate reserves contributed for about $10-12 \%$ to the final grain yield in wheat under optimal conditions, and more than $40 \%$ under drought or heat stress.

The objectives of this research were to study the effect of soil gravel content on the accumulation of dry matter during the vegetative and reproductive periods and the contribution of pre-anthesis assimilates to the grain yield of a modern and an old durum wheat variety, differing for growth patterns.

\section{MATERIALS AND METHODS}

Forty-eight open-air lysimeters of $100-\mathrm{L}$ volume $\left(0.25-\mathrm{m}^{2}\right.$ area and $0.4-\mathrm{m}$ height) were established for two years at the Department of Agronomy and Agroecosystem Management of the University of Pisa, Italy ( $43^{\circ} 40^{\prime} \mathrm{N}, 10^{\circ} 19^{\prime} \mathrm{E}$ and $1 \mathrm{~m}$ above sea level). Lysimeters were spaced $10 \mathrm{~cm}$ and were embedded in expanded clay to smooth daily fluctuations in soil temperature. Each lysimeter was attached to a $5-\mathrm{cm}$ rigid PVC drain that ended at a central collection facility. The climate is cold, humid Mediterranean with mean annual maximum and minimum daily air temperatures of 20.2 and $9.5^{\circ} \mathrm{C}$ respectively, and precipitation of $971 \mathrm{~mm}$, with $663 \mathrm{~mm}$ received from November through June.

Treatments were durum wheat varieties Cirillo and Creso, widely grown in Central Italy, and four soil gravel contents $(0,10,20$ and $30 \%$ soil volume). Cirillo is a new high-yielding variety, and Creso is an old, medium-yielding but stable variety. To determine remobilization during grain filling we harvested plants at anthesis and maturity. For each harvest stage the experiment was arranged in a randomized block design with three replications. Following the USDA soil texture description, including adjectives representing shape and kind of fragments $>2 \mathrm{~mm}$, the soils used in this experiment can be classified as non gravelly ( 0 and $10 \%$ gravel concentrations) and gravelly (20 and $30 \%$ gravel content). All are classified as cultivable soils. Gravel treatments were obtained utilizing a soil collected from a field site with $13.3 \%$ of gravel $(\varnothing>2 \mathrm{~mm})$ and $86.7 \%$ of fine earth $(\varnothing<2 \mathrm{~mm})$ by volume. Rock fragments were separated from the soil by sieving and then mixed with the fine earth at the indicated treatment proportion. The fraction of gravel with diameter higher than $2 \mathrm{~cm}$ was not used. Lysimeters were filled with soil tamped to about original soil bulk density. Soil chemical and physical properties were $27.4 \%$ sand $(2 \mathrm{~mm}>\varnothing>0.05 \mathrm{~mm}), 37.3 \%$ silt $(0.05 \mathrm{~mm}>\varnothing>$ $0.002 \mathrm{~mm}$ ), $35.3 \%$ clay $(\varnothing<0.002 \mathrm{~mm}), 7.5 \mathrm{pH}, 2.3 \%$ organic matter (Walkley and Black method), $1.2 \mathrm{~g} \mathrm{~kg}^{-1}$ total $\mathrm{N}$ (Kjeldahl method), $15.3 \mathrm{mg} \mathrm{kg}^{-1}$ available P (Olsen method), 11.6 $\mathrm{mg} \mathrm{kg}^{-1}$ available $\mathrm{K}$ (Dirks-Sheffer method). Field capacity and permanent wilting point were also determined at 33 and $1500 \mathrm{kPa}$ soil water tension using the pressure chamber method and were 27.4 and $16.3 \%$.

The durum wheat varieties were sown manually on 14 November 2001 and 20 November 2002 at a rate of 400 seeds $\mathrm{m}^{-2}$ in rows spaced $15-\mathrm{cm}$ apart. Fertilization consisted of $60 \mathrm{~kg}$ 
$\mathrm{ha}^{-1} \mathrm{~N}$ as urea, $100 \mathrm{~kg} \mathrm{ha}^{-1} \mathrm{P}_{2} \mathrm{O}_{5}$ as triple super phosphate and $100 \mathrm{~kg} \mathrm{ha}^{-1} \mathrm{~K}_{2} \mathrm{O}$ as potassium sulphate applied preplanting, and additional $120 \mathrm{~kg} \mathrm{ha}^{-1} \mathrm{~N}$ as urea at the end of tillering (1 March 2002 and 3 March 2003). Crops were irrigated when necessary to avoid water stress. As a whole, irrigation was not applied before anthesis in both years and between anthesis and maturity irrigation was applied once in 2001-2002 and four times in 2002-2003. Water was distributed utilizing a microirrigation system until field capacity was reached.

Measurements of crop growth were done at anthesis, stage 60 of the scale of Zadoks et al. (1974), on 22 April 2002 and 21 April 2003, and at physiological maturity, stage 90, on 10 June 2002 and 11 June 2003. All plants in each lysimeter were cut at ground level and were separated into leaves, culms and spikes at anthesis and into leaves, culms, chaff and grain at maturity. Harvest index (HI), number of spikes per unit area, mean kernel dry wt. and number of kernels per spike were also measured at maturity. Roots were separated from the soil by washing with water until the roots were totally clean. For dry weight determination all plant parts were oven dried at $70^{\circ} \mathrm{C}$ to constant weight.

The following parameters were calculated:

1. post-anthesis dry matter accumulation as the difference between dry matter of the whole plant at anthesis and at physiological maturity;

2. dry matter remobilization $(D M R)=$ dry matter of the whole plant at anthesis - dry matter of roots, leaves, culms and chaff at maturity;

3. dry matter remobilization efficiency $=(\mathrm{DMR} /$ dry matter of the whole plant at anthesis $) \times$ 100 ;

4. contribution of dry matter remobilized assimilates to grain $=(D M R /$ dry matter of grains at maturity) $\times 100$.

For the estimate of DMR it was assumed that all of the dry matter lost from vegetative plant parts were remobilized to the developing grain, since losses of dry matter due to plant respiration during grain filling were not determined.

Data were statistically treated by ANOVA, in order to test the main effects of year, soil gravel content and variety and their interactions. Separate statistical analyses were conducted for each harvest. Because the main effect of year and its interactions were not significant, a successive analysis of variance was carried out using years as replications. Duncan's multiple range test was used to separate the means when the ANOVA F-test indicated a significant effect of the treatment (Steel and Torrie, 1980).

\section{RESULTS}

In both years, temperature during the entire cycle and rainfall until anthesis were in line with the 120 -year averages. In contrast, as far as rainfall during grain filling is concerned, it was above average in the first season and under average in the second season. Indeed, only 10 years in the last 60 years were wettest than 2001-2002 and no driest year than 2002-2003 was recorded. Therefore, the difference between years in rainfall pattern were reset by irrigation applied during grain filling to avoid drought stress.

For all characters, the variety $\times$ soil gravel content interaction was not significant; therefore only variety and soil gravel content mean effects are discussed in the paper.

No significant genotype variation was found in grain yield and mean kernel weight, but, compared to Cirillo, Creso showed a higher number of spikes per unit area $(+11 \%)$ and a lower number of kernels per spike $(-21 \%)$. 
Grain yield, averaged over varieties, decreased progressively with the increase of soil gravel content (Table 1). Mean kernel weight was unaffected by soil gravel $(39 \mathrm{mg})$ while number of spikes per unit area and number of kernels per spike decreased progressively at increasing gravel content, so differences in grain yield owing to soil gravel content depended on both number of spikes per unit area and number of kernels per spike. Compared to control, grain yield of plants grown on $30 \%$ soil gravel content decreased by $34 \%$, number of spikes by $14 \%$ and kernel per spike by $21 \%$.

Table 1. Grain yield, number of spikes per unit area and number of kernels per spike. Soil gravel content mean values. Means followed by the same letter within the same column are not significantly different at $P \leq 0.05$

\begin{tabular}{lccc}
\hline Soil gravel content & Grain yield & Spikes & Kernels per spike \\
\hline$\% \mathrm{v} / \mathrm{v}$ & $\mathrm{g} \mathrm{m}^{-2}$ & $\mathrm{n} \mathrm{m}^{-2}$ & $\mathrm{n}$ \\
0 & $563.4 \mathrm{a}$ & $513.5 \mathrm{a}$ & $27.2 \mathrm{a}$ \\
10 & $474.4 \mathrm{~b}$ & $489.5 \mathrm{ab}$ & $24.9 \mathrm{ab}$ \\
20 & $403.0 \mathrm{c}$ & $456.0 \mathrm{~b}$ & $22.6 \mathrm{~b}$ \\
30 & $372.2 \mathrm{c}$ & $440.0 \mathrm{~b}$ & $21.6 \mathrm{~b}$ \\
\hline
\end{tabular}

Harvest index was not affected by soil gravel content and did not differ between varieties. On average, $\mathrm{HI}$ was $29 \%$.

During grain filling dry matter of leaves, culms and roots decreased, whereas, owing to grain growth, dry matter accumulation of the whole plant was evidenced. The increase of soil gravel content reduced almost linearly dry weight of all plant parts, both at anthesis and at physiological maturity (Table 2).

Genotype variation was observed only for dry weight of leaves, with cv. Creso showing $15 \%$ higher value than Cirillo at anthesis and $25 \%$ at physiological maturity (results not shown). The two varieties were significantly different for current assimilation and remobilization of dry matter during grain filling: dry matter accumulation of cv. Cirillo was $53 \%$ higher than $\mathrm{cv}$. Creso and, conversely, DM remobilization and DM remobilization efficiency were 29 and $27 \%$ lower (Table 3). As a consequence, remobilized reserves during grain filling accounted for $38 \%$ of the grain yield for Cirillo and for $57 \%$ for Creso (Table 3 ).

Compared to plants grown in gravel-free soil, the post-anthesis dry matter accumulation was about $16 \%$ higher in plants grown on gravel soil, irrespective of its content (Fig. 1). The increase of soil gravel content decreased progressively dry matter remobilization of durum wheat. Compared to control, values decreased by $15 \%$ at $10 \%$ gravel content, by $38 \%$ at $20 \%$ and by $53 \%$ at $30 \%$ (Fig. 1). Dry matter remobilization efficiency was reduced at all gravel levels, but the effect was significant only when soil gravel content was equal or higher than $20 \%$ (Fig. 1). Remobilization of dry matter accounted for over $50 \%$ of grain yield in plants grown on gravel-free soil and on soil with $10 \%$ gravel content (Fig. 1). At the two higher gravel contents, the incidence of remobilization on grain yield decreased markedly and with $30 \%$ gravel content it accounted for only $36 \%$ of grain yield (Fig. 1). 
Table 2. Dry weight of leaves, culms, spikes, roots, and whole plant and root length at anthesis and at physiological maturity. Soil gravel content mean values. Means followed by the same letter, within the same stage and column, are not significantly different at $P \leq 0.05$

\begin{tabular}{|c|c|c|c|c|c|c|}
\hline \multirow{2}{*}{$\begin{array}{l}\text { Soil gravel } \\
\text { content }\end{array}$} & \multicolumn{5}{|c|}{ Dry Weight } & \multirow[b]{2}{*}{ Root Length } \\
\hline & Leaves & Culms & Spikes & Roots & Whole plant & \\
\hline$\% \mathrm{v} / \mathrm{v}$ & \multicolumn{5}{|c|}{$\mathrm{g} \mathrm{m}^{-2}$} & \multirow[t]{2}{*}{$\mathrm{km} \mathrm{m}^{-2}$} \\
\hline & \multicolumn{5}{|c|}{ Anthesis } & \\
\hline 0 & $335.5 \mathrm{a}$ & $890.2 \mathrm{a}$ & $175.7 \mathrm{a}$ & $261.6 \mathrm{a}$ & $1663.0 \mathrm{a}$ & $26.2 \mathrm{a}$ \\
\hline 10 & $321.6 \mathrm{a}$ & $832.9 \mathrm{~b}$ & $141.4 b$ & $228.3 \mathrm{~b}$ & $1524.2 \mathrm{~b}$ & $19.8 \mathrm{~b}$ \\
\hline 20 & $280.0 \mathrm{~b}$ & $773.9 \mathrm{c}$ & $107.2 \mathrm{c}$ & $203.2 \mathrm{c}$ & $1364.3 \mathrm{c}$ & $16.1 \mathrm{c}$ \\
\hline 30 & $258.2 \mathrm{c}$ & $695.4 \mathrm{~d}$ & $89.2 \mathrm{c}$ & $191.4 \mathrm{c}$ & $1234.2 \mathrm{~d}$ & $15.4 \mathrm{c}$ \\
\hline & \multicolumn{6}{|c|}{ Maturity } \\
\hline 0 & $220.9 \mathrm{a}$ & $731.2 \mathrm{a}$ & $834.0 \mathrm{a}$ & $151.6 \mathrm{a}$ & $1937.7 \mathrm{a}$ & $15.4 \mathrm{a}$ \\
\hline 10 & $211.2 \mathrm{a}$ & $712.6 \mathrm{a}$ & $694.8 \mathrm{~b}$ & $134.5 \mathrm{~b}$ & $1753.1 \mathrm{~b}$ & $14.8 \mathrm{a}$ \\
\hline 20 & $190.4 \mathrm{ab}$ & $677.5 \mathrm{~b}$ & $596.2 \mathrm{c}$ & $123.3 \mathrm{bc}$ & $1587.4 \mathrm{c}$ & $12.7 \mathrm{a}$ \\
\hline 30 & $164.8 \mathrm{~b}$ & $634.8 \mathrm{~b}$ & $558.6 \mathrm{c}$ & $113.4 \mathrm{c}$ & $1471.6 \mathrm{~d}$ & $9.7 \mathrm{~b}$ \\
\hline
\end{tabular}

Table 3. Post-anthesis accumulation, remobilization and remobilization efficiency of dry matter and contribution of dry matter remobilization to grain yield. Variety mean values. Means followed by the same letter within the same column are not significantly different at $P \leq 0.05$.

\begin{tabular}{|c|c|c|c|c|}
\hline Variety & $\begin{array}{l}\text { Post-anthesis } \\
\text { accumulation }\end{array}$ & Remobilization & $\begin{array}{c}\text { Remobilization } \\
\text { efficiency }\end{array}$ & $\begin{array}{l}\text { Contribution of } \\
\text { remobilization to } \\
\text { grain }\end{array}$ \\
\hline Cirille & & 1761 & & 3769 \\
\hline Creso & $\begin{array}{l}291.8 \mathrm{a} \\
190.1 \mathrm{~b}\end{array}$ & $248.5 \mathrm{~b}$ & $\begin{array}{l}12.4 \mathrm{a} \\
16.9 \mathrm{~b}\end{array}$ & $\begin{array}{l}37.6 \mathrm{a} \\
56.7 \mathrm{~b}\end{array}$ \\
\hline
\end{tabular}

\section{DISCUSSION}

To understand the physiological basis for grain yield of durum wheat, the relative contribution of recent photosynthate and stored carbohydrates to the developing seed has been evaluated in two wheat varieties grown on soils differing for gravel content. The two varieties, Cirillo (a new variety) and Creso (an old variety), showed a similar behaviour, and differences in soil gravel content induced similar changes in dry matter accumulation and remobilization. However, although no consistent difference in grain yield occurred between Cirillo and Creso, the higher biomass of Creso at anthesis was associated with a higher remobilization and a lower accumulation of dry matter during grain filling. Thus, grain yield of Creso relied largely on remobilization of reserves rather than on photosynthesis and mineral uptake during grain filling. In modern cultivars, the lower partitioning of assimilates to vegetative tissues may have resulted in less vegetative carbohydrate reserves prior to anthesis than in older cultivars (Acuña et al., 2005). Therefore, recent cultivars are probably more yield sensitive than older ones to stresses that reduce photosynthesis during the period of spike formation and grain set (Slafer et al., 1993). 
Figure 1. Influence of soil gravel content on post-anthesis dry matter growth and remobilization (A) and remobilization efficiency and contribution of dry matter to grain yield (B). Vertical bars indicate standard error.
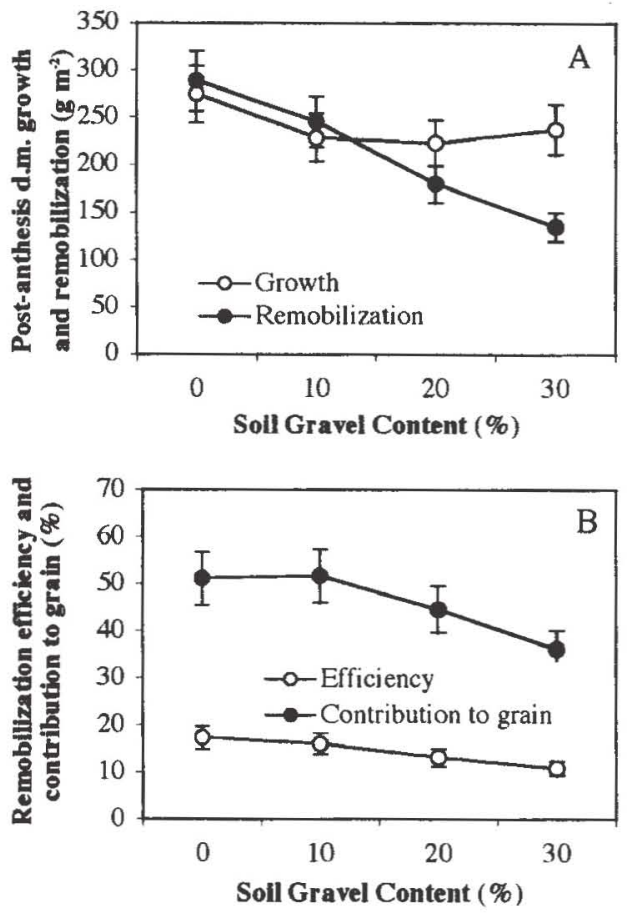

Soil gravel content decreased grain yield of durum wheat and the effect was due to the reduction of both number of spikes per unit area and number of kernels per spike. Already at anthesis the increase of the soil gravel content decreased growth of culms, leaves, spikes and roots, thereby reducing the size of both the source, represented by photosynthetizing biomass and nutrient uptake ability by roots, and the sink, represented by the number of spikes per unit area and the number of kernels per spike, for grain growth. 
Post-anthesis dry matter accumulation was not greatly affected by gravel content, while dry matter remobilization was markedly reduced, especially at gravel levels equal or higher than 20\%. Thus, $20 \%$ gravel content represents a critical limit for the remobilization of assimilates. Thereby, at soil gravel contents equal to 0 and $10 \%$, post-anthesis growth and remobilization were similar, while at soil gravel levels higher than $10 \%$ growth exceeded remobilization.

In this research, the reduced growth of wheat plants produced by soil gravel content may be attributed to the restriction of root zone volume that in turn may result either from a decreased absorption of water and nutrients by the limited root system or from a change in the level or of activity of endogenous factors which are influenced by the roots and affects the growth of the plant (Carmi and Heuer, 1981). Severe mineral deficiency was not likely to occur, since $\mathrm{N}$ and $\mathrm{P}$ fertilization rate per unit area was the same at all gravel treatments. Also water deficiency, which may be expected in gravelly soils, in our experiment was not likely to occur, because during the tillering and jointing stages rainfall was high, and even exceeded soil waterholding capacity.

Although critical conditions found in this research cannot be directly referred to field conditions as experiments were carried out in lysimeters, we believe that the treatments applied (i.e. linearly increasing soil gravel content) allow to elucidate the casual relationship between the mechanisms of growth inhibition and soil gravel content. Moreover, grain yield and post anthesis remobilization of assimilates are in line with results fron field experiments in the same area.

In conclusion, we believe that soil gravel affected grain yield and plant growth of durum wheat mainly by the restriction of the volume of soil available for root growth, which caused an increased filling of empty pores by roots. As a consequence, the gaseous exchange between soil and atmosphere, the water flow in soil, and finally the root size and functionality were all reduced. Since the effects on plant size were already evident at anthesis, these unfavorable conditions were set up approximately from the stem elongation stage, when plant growth was consistent. Because the amount of translocated dry matter depends on the relative amount present in the plant at anthesis, soil gravel content also reduced their remobilization during grain filling and, consequently, the dry matter produced at maturity.

\section{REFERENCES}

Acuña ML, Savin R, Curà JA, Slafer GA (2005) Grain protein quality in response to changes in pre-anthesis duration in wheats released in 1940, 1964 and 1994. J. Agron. Crop Sci. 191: $226-232$

Austin RB, Edrich JA, Ford MA, Blackwell RD (1977) The fate of dry matter, carbohydrates and ${ }^{14} \mathrm{C}$ lost from the leaves and stems of wheat during grain filling. Ann. Bot. 41: 13091321

Bidinger FR, Musgrave RB, Fisher RA (1977) Contribution of stored pre-anthesis assimilate to grain yield in wheat and barley. Nature 270:431-433

Carmi A, Heuer B (1981) The role of roots in control of bean shoot growth. Ann. Bot. 48: 519-527

Cox MC, Qualset CO, Rains DW (1985) Genetic variation for nitrogen assimilation and translocation in wheat. II. Nitrogen assimilation in relation to grain yield and protein. Crop Sci. 25: 435-440 
Danalatos NG, Kosmas CS, Moustakas NC, Yassoglou N (1995) Rock fragments. II Their impact on soil physical properties and biomass production under Mediterranean conditions. Soil Use Manage. 11: 121-126

Gebbing T, Schnyder H, Kühbauch W (1999) The utilization of pre-anthesis reserves in grain filling of wheat. Assessment by steady-state ${ }^{13} \mathrm{CO}_{2}{ }^{12} \mathrm{CO}_{2}$ labelling. Plant Cell Environ. 22, $851-858$

Gee GW, Wierenga PJ, Andraski BJ, Young MH, Fayerand MJ, Rockhold ML (1994) Variations in water balance and recharge potential at three western desert sites. Soil Sci. Soc. Am. J. 58: 63-72

Kosmas CS, Danalatos NG, Moustakas N, Tsatiris B, Kallianou C, Yassoglou N (1993) The impacts of parent material and landscape position on drought and biomass production of wheat under semi-arid conditions. Soil Technol. 6: 337-349

Kosmas C, Moustakas N, Danalatos NG, Yassoglou N (1994) The effect of rock fragments on wheat biomass production under highly variable moisture conditions in Mediterranean environments. Catena 23: 191-198

Poesen J (1990) Erosion process research in relation to soil erodibility and some implications for improving soil quality. In: Albaladejo J, Stocking MA, Diaz E (Eds.), Soil degradation and rehabilitation in Mediterranean environmental conditions. CSIC, Murcia, pp. 159-170

Poesen J, Ingelmo-Sanchez F (1992) Runoff and sediment yield from topsoils with different porosity as affected by rock fragment cover and position. Catena 19: 451-474

Poesen J, Lavee H (1994) Rock fragments in top soils: significance and processes. Catena 23: $1-28$

Ravina I, Magier J (1984) Hydraulic conductivity and water retention of clay soils containing rock fragments. Soil Sci. Soc. Am. J. 48, 736-740

Slafer GA, Andrade FH, Satorre EH (1993) Increases in grain yield in bread wheat from breeding and associated physiological changes, in: Slafer GA (Ed), Genetic improvement of field crops. Marcel Dekker, New York, pp. 1-68

Steel RGD, Torrie JH (1980) Principles and procedures of statistics, McGraw-Hill, New York van Herwaarden AF, Angus JF, Richards RA, Farquhar GD (1998) 'Haying-off', the negative grain yield response of dry-land wheat to nitrogen fertiliser. II. Carbohydrate and protein dynamics. Aust. J. Agric. Res. 49: 1083-1093

van Wesemael B, Poesen J, Kosmas CS, Danalatos NG, Nachtergaele J (1996) Evaporation from cultivated soils containing rock fragments. J. Hydrol. 182: 65-82

Zadoks JC, Chang TT, Konzak CF (1974) A decimal code for the growth stages of cereals. Weed Res. 14: 415-421

Received 22 February, 2006, accepted 31 August, 2006 